\title{
Relationship Between the Percentages of Crude Protein and Apparently Digestible Protein in Some Forages of Puerto Rico
}

\author{
José A. Arroyo-Aguilu and Luis Rivera-Brenes ${ }^{1}$
}

\section{INTRODUCTION}

A relationship between the percentages of crude protein and apparently digestible protein in forages has been evident since 1869. Mitchell $(9)^{2}$ in Illinois and Dijkstra (6) in Holland observed this relationship and presented supporting data. Regression equations and correlation coefficients $(v)$ have been computed by several workers. Glover et al. (7) in Kenya expressed this relationship by means of the following equation: $Y=69.7$ $\log X-13.9$ where $Y=$ percentage of apparently digestible protein and $X=$ percentage of crude protein. Holter and Reid (8) in New York expressed the highly significant correlation of +0.995 by the equation $Y=$ $0.929 X-3.48$. In New Jersey Baumgardt (5) obtained a correlation coefficient $(r)$ of +0.99 and calculated the regression equation $Y=$ $0.931 X-3.619$.

This study was undertaken to determine the correlation between percentages of crude protein and of apparently digestible protein, and to develop a regression equation that would fit the data.

\section{PROCEDURE}

In this study data on percentages of crude protein and of apparently digestible crude protein obtained in experiments conducted by Arroyo and Rivera Brenes $(1,2)$ were used. Conventional digestion trials were conducted with Venezuela grass (Paspalum fasciculatum) (1) in 1958, and with Napier (Merker) grass (Pennisetum purpureum), Giant Pangola grass (Digitaria valida Stent), and Signal grass (Brachiaria brizantha) (2) in 1960. Data on digestion trails conducted in 1963 with Buffel grass (Pennisetum ciliare), Guinea grass hybrid (Panicum maximum), and Napier (Merker) grass (Pennisetum purpureum) have not been published yet (3).

Each experiment consisted of a 7-day preliminary feeding period and a 5 -day collection period. Each observation (table 1) represents the average for three cows, except the first, which represents the average for two cows. All forage offered and refused, as well as all feces voided, was carefully

1 Assistant Biochemist and Head, respectively, Animal Husbandry Department, Agricultural Experiment Station, University of Puerto Rico, Río Piedras, P.R.

- Italic numbers in parentheses refer to Literature Cited, pp. 147-8. 
weighed. Both forage and feces samples were collected daily $(1,2)$. Crudeprotein determinations were made according to the Methods of Analysis of the Association of Official Agricultural Chemists (A.O.A.C.) (4).

The statistical analyses of correlation and regression were made according to Steel and Torrie (10).

\section{RESULTS AND DISCUSSION}

It is important to know the digestible-protein content of a forage because of its great value in livestock feeding. Protein is rationed to ruminants on

TABLE 1.-Relationship between predicled and actual digestible-protein values for various forage grasses in Puerto Rico

\begin{tabular}{|c|c|c|c|c|c|}
\hline Forage grass & Age & Crude protein & $\begin{array}{c}\text { Predicted } \\
\text { digestible } \\
\text { protein }\end{array}$ & $\begin{array}{c}\text { Actual } \\
\text { digestible } \\
\text { protein }\end{array}$ & Deviation \\
\hline $\begin{array}{l}\text { Venezuela } \\
\text { Signal } \\
\text { Merker } \\
\text { Giant Pangola } \\
\text { Signal } \\
\text { Merker } \\
\text { Giant Pangola } \\
\text { Buffel } \\
\text { Guinea hybrid } \\
\text { Merker } \\
\text { Buffel } \\
\text { Guinea hybrid } \\
\text { Merker }\end{array}$ & $\begin{array}{l}\text { Days } \\
40-60 \\
50 \\
50 \\
50 \\
80 \\
80 \\
80 \\
49-55 \\
49-55 \\
49-55 \\
63-69 \\
63-69 \\
63-69\end{array}$ & \begin{tabular}{r|} 
Percent \\
6.41 \\
6.07 \\
8.30 \\
6.29 \\
4.66 \\
5.23 \\
5.43 \\
6.96 \\
6.50 \\
8.03 \\
6.25 \\
5.63 \\
6.68
\end{tabular} & $\begin{array}{r}\text { Percent } \\
3.20 \\
2.92 \\
4.75 \\
3.10 \\
1.77 \\
2.23 \\
2.40 \\
3.65 \\
3.19 \\
4.53 \\
3.07 \\
2.56 \\
3.42\end{array}$ & $\begin{array}{c}\text { Percent } \\
2.97 \\
2.22 \\
4.28 \\
2.79 \\
1.87 \\
2.13 \\
2.41 \\
4.03 \\
3.91 \\
4.90 \\
2.71 \\
3.00 \\
3.66\end{array}$ & $\begin{array}{l}\text { Perceisl } \\
-0.23 \\
-.70 \\
-.47 \\
-.31 \\
+.10 \\
-.10 \\
+.01 \\
+.38 \\
+.72 \\
+.37 \\
-.64 \\
+.44 \\
+.24\end{array}$ \\
\hline Sum & & 82.44 & 40.79 & 40.88 & -.19 \\
\hline Average & & 6.34 & 3.14 & 3.14 & \\
\hline
\end{tabular}

the basis of apparently digestible protein. The digestible-protein content measures the potential possibilities of a forage (11). Crude-protein content merely measures the chemical composition of protein in the forage and in the feces.

A regression equation was calculated to predict percentage digestibleprotein content $(Y)$ from percentage crude-protein content $(X)$ on a drymatter basis. A highly significant correlation of 0.90 was obtained, indicating the close relationship between crude-protein and digestible-protein values and supporting the concept that digestible protein can be predicted as accurately as it can be determined in a conventional digestion trial. The equation computed was $Y=0.819 X-2.05$. 
By means of this equation percentage of predicted digestible-protein content (table 1) was calculated for all samples. The standard error of the deviation between actual and predicted digestible-protein content was found to be 0.44 percent. Further research based on a larger number of observations is indicated to test the accuracy of the prediction equation.

\section{SUMMARY}

A study was undertaken to determine the relationship between percentages of crude protein and of apparently digestible protein in some forages of Puerto Rico.

A regression equation was developed to predict the percentage digestibleprotein content $(Y)$ from percentage crude-protein content $(X)$ on a drymatter basis: $Y=0.819 X-2.05$. A highly significant correlation of 0.90 was obtained. Using this same equation, the percentage predicted digestibleprotein content (table 1) was calculated for all samples.

\section{RESUMEN}

Se llevó a cabo un estudio para determinar la relación entre los porcentajes de proteína bruta y proteína digestible aparente en algunas yerbas forrajeras en Puerto Rico.

Se desarrolló una ecuación de regresión para determinar, del porcentaje de proteína bruta $(X)$, el porcentaje de proteína digestible $(Y)$, a base seca: $Y=0.819 X-2.05$. Se obtuvo una correlación altamente significativa de 0.90 . Usando esta misma ecuación, se calcularon los porcentajes de proteína digestible (tabla 1) para todas las muestras.

\section{LITERATURE CITED}

1. Arroyo-Aguilú, J. A., and Rivera Brenes, L., Digestibility studies on Venezuela grass (Paspalum fasciculalum) and plantain pseudostalks (Musa paradisiaca), J. Agr. Univ. P.R. 44(3): 103-6, 1960.

2. - and - - Digestibility studies on Napier (Merker) grass (Pennisetum purpureum), Giant Pangola grass (Digitaria valida Stent) and Signal grass (Brachiaria brizantha), J. Agr. Univ. P.R. 45(3): 151-6, 1961.

3. Arroyo-Aguilú, J. A., and Rivera Brenes, L., unpublished data.

4. Official Methods of Analysis, Assn. Agr. Chem., 9th ed., Washington, D.C., 1960.

5. Baumgardt, B. R., Taylor, M. W., and Cason, J. L., Evaluation of forages in the laboratory, II, Simplified artificial rumen procedure for obtaining repeatable estimates of forage nutritive value, $J$. Dairy Sci. $45(1): 62-8,1962$.

6. Dijkstra, N. D., What has the State Agricultural Experiment Station at Hoorn contributed to research into the feeding value of roughage? Netherlands $J$. Agr. Sci. 2: 273-97, 1954.

7. Glover, J., Duthie, D. W., and French, M. H., The apparent digestibility of crude protein by the ruminant, I, A synthesis of the results of digestibility trials with herbage and mixed feeds, $J$. Agr. Sci. 48: 373-8, 1957.

8. Holter, J. A., and Reid, J. T., Relationship between the concentrations of crude protein and apparently digestible protein in forages, J. Anim. Sci. 18: 1339-49, 1959. 
9. Mitchell, H. H., The evaluation of feeds on the basis of digestible and metabolizable nutrients, J. Anim. Sci. 1: 159-73, 1942.

10. Steel, R. G. D. and Torrie, J. H., Principles and Procedures of Statistics, McGraw-Hill Book Co., Inc., New York, N.Y. 1960

11. Swift, R. W., The Nutritive Evaluation of Forages, B. 615, Pa. State Univ., Univ. Park, Pa., January 1957. 